\title{
Public Relations as Covert Political Communication: The Debate over Public vs. Private Utilities in the United States
}

\author{
By David E. Nye
}

Odense University

The present essay has several purposes: (1) to demonstrate the qualitative difference between public relations and advertising, (2) to provide a model of public relations as a form of communication, and (3) to ground these observations on a case study of a well-documented historical example. The particular case, the public relations activities of American utilities in favor of private rather than public ownership, serves all three purposes. The utilities recognized the differences between advertising and public relations and created a special agency to express their political opinions indirectly. A Federal investigation of their activities yielded thousands of pages of testimony and printed evidence. These extensive materials permit generalizations about public relations as a form of communication.

No one can doubt the importance of public relations in the history of twentieth century America. Virtually every major corporation maintains an extensive in-house staff that works exclusively on public relations. And since these are cost-conscious, profit-oriented organizations, it seems reasonable to assume that corporations find it worth the investment. Yet despite the obvious presence of public relations as a major part of contemporary culture, comparatively little historical work has been done on the development of this profession beyond a scattering of articles and Alan Raucher's Public Relations and Business: 
1900-1929. Given the paucity of work with primary materials, most interpretive studies of twentieth century United States history have ignored public relations, focusing instead on advertising. Daniel Boorstin's The Americans does not mention the subject except in passing, but devotes more than twenty pages to the growth of advertising, which he calls, "the omnipresent, most characteristic, and most remunerative form of American literature." Nor does Stanley Aronowitz's more radical interpretation of industrial society in False Promises contain anything on public relations, although it too looks at advertising in detail. Even specialized works on the history of newspapers and magazines have scarcely touched the subject. Neither Frank Luther Mott's landmark American Joumalism nor the standard text The Press in America discusses public relations, limiting themselves to histories of the major wire services. In these works, as elsewhere, public relations has not been recognized as an important subject, and advertising alone has received scholarly attention. ${ }^{1}$

Between 1890 and 1930, the United States developed the most extensive system of utilities in the world, including gas works, electrical distribution systems, telephone lines, and improved water systems. Yet these were not all developed in the same way. Some were public, others private, and the question of which form of ownership was appropriate became a staple of national political debate. Indeed, aspiring college orators could purchase special handbooks presenting the affirmative and negative sides of the question. As early as 1906 the public's interest in this problem became so intense that the Brooklyn Public Library prepared an annotated list of works on the subject, numbering more than 75 books. ${ }^{2}$ Every newspaper carried editorials on public versus private utilities; every politician had to take a stand on the subject. Not a month went by when magazines such as The Survey, The North American Review, Outlook, and The Review of Reviews failed to carry an article on it. Each community debated the issue, since it was a matter of local control, and in some cases they installed municipal plants. The majority of American electrification, however, remained private. While certain cities and many centers overseas chose municipal control, most American cities did not. ${ }^{3}$

The debate focused not only on lighting, but on all other utilities as well. Advocates of municipal ownership called for elimination of private street car companies, gas works, lighting plants, telephone and telegraph companies, and in some cases railroads as well. Had they won the fight, American city governments would have wielded much more power than they do today. 'More importantly, from industry's 
point of view, the nature of its market would have been quite different. To protect their interests, the large electrical manufacturers made common cause with the private utilities, attacking public ownership on a wide front. While many of their attacks were direct and above board, the majority were covert, utilizing third parties to discredit or to undermine opposing positions. These clandestine activities became the subject of a Senate ordered investigation under the auspices of the Federal Trade Commission between 1928 and 1934. ${ }^{4}$ Few have studied the findings of this investigation since the 1930's, however, and as the issue has cooled considerably in the interval, a brief summary of the two sides of the debate may be useful. In many respects, the debate anticipated the present controversy over public versus private cable television systems, and other similar issues.

Those for public ownership argued that utilities naturally devolved upon municipalities, because they were uniform services that every citizen used and required. ${ }^{5}$ Just as cities operated fire departments, water lines and the highway system, used by all citizens, so too they ought to control the electrical power plant and the grid of lines which extended from it. Supporters argued that municipal ownership was not socialistic - in most cases attempting to separate the issue from overt ideology. They noted that the electrical system could not be regulated through competition, and that it necessarily would be run as a monopoly. Private ownership of such a monopoly created many potential evils. Businessmen could not operate efficiently without the check of competition, and private systems would therefore be wasteful. In addition of this waste, the private system would be run for a profit, in effect giving a private group the right to tax every citizen. A private utility might plunder the public, and it would not be held accountable. To protect its interests, such a monopoly necessarily would attempt to control local assemblymen and aldermen. Private utilities would therefore tend to bribe local officials; they would lower moral standards. And should they be run poorly, every citizen would pay for private mistakes, in effect violating the fundamental American principle of no taxation without representation. Supporters of municipal ownership also pointed out that private owners would wish to expand consumption of electricity beyond necessary levels, installing more lighting systems in a town than were needed, for example. Such a monopoly would grow as much as possible, keeping its own interests ahead of those of the citizens.

Aside from these negative arguments, the supporters of municipal power saw clear advantages in public ownership. It would remedy 
most of the evils of private monopoly, by running plants for public benefit, lowering service rates, reducing taxes with any profits made, and avoiding needless investments. As a voter, every taxpayer would virtually be a stockholder in the public corporation, preventing corruption and mismanagement.

These arguments appealed strongly to the reform elements in American politics, particularly members of the short-lived Populist and Progressive parties. When properly presented, the municipal ownership position could appeal to most Americans on the same grounds that they preferred public to private police forces, water departments, libraries, fire companies, and the like.

But on the other side, proponents of laissez-faire economics and free enterprise made a powerful case for private control. ${ }^{7}$ They attacked governmental expansion in any part of the private sector, and argued that public corporations were generally mismanaged because they fell into the hands of corrupt politicans, rather than being run on sound business principles and governed by self-interest. Public utilities would lose money because they did not need to make it. They would become a drain on the treasury, in effect raising taxes. The public clamor for low rates would weaken the financial position of the utilities, making investment in new equipment difficult, if not impossible. Furthermore, public utilities would lose their most competent managers to private enterprises, which offered more room for advancement and remained alert to new technologies. Public managers would be underpaid and thus often incompetent. They would be subject to pressures with every shift in local politics. The utility itself would be forced to hire many political friends and relations. Instead of providing public service, it would provide jobs. Instead of lowering costs, it would increase them. Instead of making a community stronger, it would weaken an essential service, while distracting politicians from other tasks that they must perform. After 1919 those against public utilities often advanced their position under the banner of anti-communism and anti-socialism, adding a rather predictable rhetoric to their position. But even without that rhetoric they made a strong case, which could appeal to most Americans.

These positions each had the appearance of logic, practical experience, and acceptable ideology. In the abstract, either might be correct. Therefore, most debates were lost or won based on actual case studies - communities where power cost more or less, depending upon whether it was public or private. As is usually the case in American politics, practical examples proved more important than theory, and 
most newspaper and magazine stories focused upon a single incident or case to make a more general point. ${ }^{8}$ Over a period of three decades before the Great Depression, Americans examined each municipality's system, seeking to find a general truth in the welter of facts. During much of the 1920's, large projects such as the proposed damming of the Tennesee River Valley were hotly debated without resolving the issue of public versus private power. ${ }^{9}$ The debate was not only defined by its intellectual content, however, but also through the means by which information reached the public.

The adversaries in the debate were not only citizen groups. Large private utilities banded together to protect their economic interests, making the National Electric Light Association (NELA) their umbrella organization after 1915. Thus NELA, which had previously served as a General Electric holding company, became a public relations organization, with a new headquarters in New York City. ${ }^{10}$ During the First World War its activities were minor, but in the 1920's NELA ran an enormous public relations campaign against government ownership of utilities. This campaign addressed the entire American population, working through a wide variety of institutions, including the high schools, colleges, Rotary Clubs, women's clubs, newspapers, magazines, publishers, and virtually any other media or institutional forum. The scale and scope of this public relations effort was a large as the advertising campaigns of the same years, repeatedly reaching virtually every voting citizen. ${ }^{11}$

Most of these public relations efforts were covertly funded, and did not bear any company name. Thus, for example, NELA supported a news agency in the Northwest which sent articles to newspapers in that region. Editors picked them up as "news" rather than as advertising, and published them free. Often the newspapers did not know the origin of the stories. ${ }^{12}$ Across the nation, NELA's publicity men distributed articles and even editorials which regularly appeared in the local papers. Some newspapers printed as much as fifty percent of all materials received..$^{13}$ The extent of the NELA's media penetration can best be understood through examples. During one year in Louisiana and Misissippi fifty-two newspapers carried more than 4,500 column inches of material. In New England during 1923, newspapers carried the equivalent of 156 pages, in Missouri, 334 pages, of unacknowledged public relations. In both cases more than ten percent appeared in the form of editorials and letters from prominent citizens. Many of these "letters" were in fact composed in the offices of the publicity committee, and then signed by prominent local individuals. ${ }^{14}$ 
most newspaper and magazine stories focused upon a single incident or case to make a more general point. ${ }^{8}$ Over a period of three decades before the Great Depression, Americans examined each municipality's system, seeking to find a general truth in the welter of facts. During much of the 1920's, large projects such as the proposed damming of the Tennesee River Valley were hotly debated without resolving the issue of public versus private power. ${ }^{9}$ The debate was not only defined by its intellectual content, however, but also through the means by which information reached the public.

The adversaries in the debate were not only citizen groups. Large private utilities banded together to protect their economic interests, making the National Electric Light Association (NELA) their umbrella organization after 1915. Thus NELA, which had previously served as a General Electric holding company, became a public relations organization, with a new headquarters in New York City. ${ }^{10}$ During the First World War its activities were minor, but in the 1920's NELA ran an enormous public relations campaign against government ownership of utilities. This campaign addressed the entire American population, working through a wide variety of institutions, including the high schools, colleges, Rotary Clubs, women's clubs, newspapers, magazines, publishers, and virtually any other media or institutional forum. The scale and scope of this public relations effort was a large as the advertising campaigns of the same years, repeatedly reaching virtually every voting citizen. ${ }^{11}$

Most of these public relations efforts were covertly funded, and did not bear any company name. Thus, for example, NELA supported a news agency in the Northwest which sent articles to newspapers in that region. Editors picked them up as "news" rather than as advertising, and published them free. Often the newspapers did not know the origin of the stories. ${ }^{12}$ Across the nation, NELA's publicity men distributed articles and even editorials which regularly appeared in the local papers. Some newspapers printed as much as fifty percent of all materials received..$^{13}$ The extent of the NELA's media penetration can best be understood through examples. During one year in Louisiana and Misissippi fifty-two newspapers carried more than 4,500 column inches of material. In New England during 1923, newspapers carried the equivalent of 156 pages, in Missouri, 334 pages, of unacknowledged public relations. In both cases more than ten percent appeared in the form of editorials and letters from prominent citizens. Many of these "letters" were in fact composed in the offices of the publicity committee, and then signed by prominent local individuals. ${ }^{14}$ 
Around the country the practices were similar, as NELA had divided North America into regions and sent each the same materials. In short, most citizens regularly received carefully prepared propaganda disguised as news or as letters to the editor.

NELA was only the initiator of the campaign, as a "propaganda holding company," coordinating many apparently unrelated efforts throughout the electrical industry. Its sizable annual budget was miniscule compared to those of its many members, who often paid for local printing and distribution of materials. The Federal Trade Commission found that local utilities allotted one and one half percent of their gross revenue for public relations and advertising, spending more than $\$ 25,000,000$ in 1927 alone. In many of these cases, NELA provided literature and/or ideas, which the local organizations used. As a result, estimates of the true cost of the NELA compaign cannot be made, but certainly overall expenses were more than double its budget.

Such covert communication would play an enormous role in American social and economic life in the twentieth century. It disrupted the earlier processes which Americans had used to arrive at generally held opinions. A society which had cultivated debate and public oratory in the nineteenth century, in which many individuals had the opportunity to impress their views on local audiences, became a society dominated by a few centers of opinion, from which emanated a torrent of magazines, books, telegraphed opinions, and photographs. Through news bureaus and wire services, organizations could unobtrusively insert material into public debate through third parties. The creation of NELA demonstrates that large industries understood the benefits of such indirect communication. The organization included virtually every utility in North America, and other industrial sectors created similar institutions. These were collectively the logical extension of ogopolistic power, providing a favorable social context for the overt advertising messages of individual companies. Professional public relations firms developed almost entirely in the twentieth century, as an ally of advertising, but whose forms of influence proved far more versatile and influential almost as an direct function of their degree of indirectness. ${ }^{15}$

Communication through newspapers and magazines apparently is straightforward. A known sender addresses the reader, who understands the message of the story within the context where it appears. An editorial apparently represents the newspaper editor's opinion, a letter to the editor expresses the views of someone outside the paper, 
and a story in theory should be a reasonably objective presentation of facts without intentional distortion. But when a publication acts as proxy for someone else, the reader encounters a new kind of message, attributing to the story, editorial, or letter a context and an origin which are incorrect. The meaning of the message is not the same as it would be in a paid political advertisement, for example.

The nature of this change in the communication situation, in essence the difference between straightforward advertising and public relations, can be seen more clearly when compared to other forms of indirect communication. For example, Paul Bouissac has examined the ways in which circus trainers direct and control animal performances. ${ }^{16}$ The animal responds to hidden cues, but appears to be answering questions or obeying verbal commands. The audience watches the act without observing the code which actually is operating between the animal and its trainer. Missing the covert cues employed, it focuses upon the verbal commands it can understand, and to which the horse or monkey appears to answer or respond. Because the audience understands the animal act in the context of human communication (language) and not in the context of cued behavior (the trainer's signals and his animal's responses), it experiences the illusion of an animal with superior intelligence.

For this kind of mistake to occur, the "trainer" need not even be conscious of the existence of a hidden code in use between himself and the animal. In the famous case of "Clever Hans," a horse appeared to have extraordinary intelligence, but in fact responded to cues that its owner was unaware that he gave to the animal. ${ }^{17}$ The horse became celebrated for his apparent ability to add, subtract, multiply, and perform other complex operations, when in fact he only moved in accord with the tilt of his master's wide-brimmed hat. This unconscious communication was eventually discovered, and the horse revealed to have no special powers.

In the case of "Clever Hans" or a circus act, communication only appears to occur between the audience and the animal. In actuality, the audience communicates with the trainer, who uses the horse as an intermediary. Similarly, in the case of public relations, the newspaper only appears to address the public, serving as a conduit for a third party. Whether the editor has intentionally published public relations material or not does not change the structure at all, from the audience's point of view. In either case, the public receives a message that has been "laundered" of one set of associations and given another set. What would have appeared as a paid political notice, now seems to 
be the opinion of a local citizen, a reporter, or an editor. Just as the circus act creates the illusion of intelligence where one expects none, so too the well placed public relations story creates the illusion of objectivity and unbiased discussion that favors a particular interest group such as NELA.

Of course, at the circus the communication situation as a whole is framed entirely differently than in a newspaper. The audience, trainer, and animal are present in one room. The audience knows that it will be tricked; it pays for that experience, and expects it to be convincing. But in the case of a newspaper article placed by corporate public relations, the three parties are not all in one room, but widely separated in space and time. The communication does not occur in a priviledged space where trickery and hidden cues are expected and permitted, but in the arena of public debate. The public has not paid for the newspaper in order to receive covert advertising, but rather to get accurate information.

But just as the public enjoys seeing a horse counting with its foot, to reach the correct answer to a mathematical problem, while it would find the trainer's ability to solve the problem not only uninteresting but a poor performance indeed, so too the average citizen is far more impressed to find that a local citizen, who apparently has no reason to favor private utility ownership, has taken time to write a thoughtful letter to the newspaper, than to read a political advertisement. Just as the citizenry would boycott a circus where trainers replaced animals, so too it would not buy a newspaper full of paid political announcements instead of news. By hiding a message's origin, its meaning is enhanced. Public relations, in brief, consists in shifting contexts and changing speakers, to deliver the same message that advertising might also deliver, but that few would bother to read, were its origin known.

One may diagram the communication situation created by public relations as follows. ${ }^{18}$

\section{first second \\ context context}

Sender - channel - message - channel - message - reciever

No. $1 \quad$ No. 2

(NELA) ("news"

(newspaper)

(reader)

agency)

While the message remains the same - indeed NELA often sent newspapers ready-made boiler plate which could be put right on the 
press - the context and the channel used to deliver that message have changed. As a result, the receiver cannot code the message correctly, mistaking advertising for "news." Even if NELA did not lie about content, it did falsify all the other constituents of the communication.

Furthermore, there were cases when NELA distributed false information, making the deception total. For example, NELA spread incorrect statistics about the actual success of municipal power plants, creating the impression that they compared unfavorably with privately owned utilities. One conspicuous example of this practice was a handsomely printed pamphlet sent to every member of the United states Congress and to many universities in $1926 .{ }^{19}$ Professor E.A. Stewart of the Agricultural Engineering Department of the University of Minnesota authored the work, entitled "Electricity in Rural Districts Serviced by the Hydro-Electric Power Commission of the Province of Ontario, Canada." The booklet appeared under Stewart's name, with no reference to NELA, which had sponsored the research, paid for the printing, and mailed the result. Stewart was a well known utility expert, and he filled his apparently scientific report with charts and statistics that "proved" the largest public power project in North America - in Ontario Province - did not deliver electricity at a lower cost than private utilities. He concluded: "No miracle of cheap electricity is to be found on Ontario farms ... Nowhere in Ontario did I find actual costs of rural service out of line with the cost to the farmer in the United States." In fact, the case was quite the reverse, as Ontario farmers paid on average only $40 \%$ what American farmers paid for electricity. ${ }^{20}$ This deception was not an isolated example, but a matter of NELA policy. Time and time again it distributed false information, which purported to show that municipal power companies had lost money or that they provided more expensive service than private companies in similar locations.

In these cases, the entire communication became a falsehood, including the message, the apparent sender of that message, its social context, and the means of contact employed. Unlike the circus, where the deception is harmless, in the case of the partner utilities in NELA, the trickery was worth millions of dollars in profits. Mastery of the media through public relations permitted the company to distort the political discussion on public ownership of the utilities. This appears to be an extreme statement of the case, but there are innumerable examples. Not only did the corporation utilize bogus news agencies and cooperative college professors to disseminate itw views, but it also encouraged the rewriting of school textbooks, published books for 
school libraries, campaigned for removal of other books from the curriculum, sponsored conferences, endowed scholarship funds, supported research favorable to its interests, paid speakers to travel the country expounding "correct" views, sponsored essay contests, made non-interest bearing deposits in banks to secure their support, broadcast to more than ten million persons a year over the radio, and sought to spread NELA approved opinions through civic and professional organizations in the insurance industry and through members' contacts with chambers of commerce. ${ }^{31}$ The total effect of these activities cannot easily be assessed or summarized, since they lasted more than a decade and altogether cost more than $\$ 10,000,000$ in direct expense to NELA, as well as many other costs borne by the individual utilities that were members.

These activities only came to light because the United States Senate launched an investigation into the utility corporations, carried out by the Federal Trade Commission between 1928 and 1934. The results of that inquiry filled more than eleven thousand pages, yet they were incomplete. General Electric's involvement was extensive, but the corporation's name scarcely appears in the 500 page index, and the origin of NELA as a General Electric holding company escaped the investigatiors' attention. Nor did the Federal Trade Commission emphasize the extensive involvement of General Electric's chief officers in the NELA campaign, except in the briefest notes. Owen D. Young, Chariman of the Board, served on the powerful publication committee. Gerard Swope, Company President, helped to distribute 33,000 copies of a NELA pamphlet entitled "A Symposium: Common Interdependence of Labor and Electric Power in the United s t a te . 'And Bruce Barton, the company's chief advertising advisor, served NELA in a similar capacity. He authored an article for the first issue of its magazine, Light, and throughout the 1920's prepared envelope enclosures that utility comapnies inserted with their monthly bills. They were called, inside NELA, "Bruce Barton envelope stuffers." $\mathrm{He}$ regularly received a retainer of $\$ 5,000$ for his services, which included the preparation of short booklets. In 1926, NELA spent $\$ 199,000$ just to print them. ${ }^{23}$

A these examples demonstrate, General Electric's chief offiers and advertising advisor were intimately involved in the publicity efforts. NELA's total budget for these activities rose from just over $\$ 500,000$ in 1923 , to more than $\$ 1,000,000$ in 1928 . General Electric contributed something more as well, in the form of services from its Publicity Department, with its staff over 200 professional artists, photographers, 
and writers. In particular, it lent NELA one of its most effective public speakers, Charles M. Ripley, who had previously written two classic works of welfare capitalism, Life in a Large Manufacturing Plant and The Romance of a Great Factory. In the last years of the 1920's Ripley traveled widely, delivering an illustrated lecture entitled "The Romance of Power." ${ }^{4}$ In four months alone, beginning in September, 1927, he gave the lecture more than one hundred times, at an expense to NELA of $\$ 3100$. During just the first three weeks of this tour, Ripley reached twenty audiences in Ohio, Indiana, Kentucky, and West Virginia. His travel had been carefully planned, to minimize backtracking or wasted motion, and he often delivered his lecture more than once a day. He regaled the Youngstown Optomist club, The Warren Ohio Kiwanis Club, The Cleveland Engineering Society, the Akron Rotary Club, and many schools as well. In those three weeks he spoke to 6500 business and community leaders, answering their questions, and arguing for the private ownership of power. Ripley's talk proved so successful that NELA decided to print 27,000 copies, which it then distributed to schools and colleges. ${ }^{25}$

Although he was active in this work for several years, Ripley could not travel widely enough to suit his superiors. NELA therefore made fifty copies of the 104 slides which formed the visual core of his talk, and sent out trained lecturers to every part of the country to deliver it. ${ }^{21}$ The extensive use of slides in the lecture highlights another difference between advertising and public relations. While General Electric used images extensively in its product advertising, NELA used many less. The reasons for this difference were hardly economic, since both organizations had immense sums of money to spend. Rather, the corporation needed the photograph as an apparently unbiased form of evidence whenever it communicated directly with its employees or the public. The photograph seemed a neutral and unbiased element supporting the company message. In the case of the covert newspaper message, however, photographs were not needed in order to make the communication appear to be objective. Not only were photographs unnecessary in the newspaper, which itself was the guarantor of objectivity, but photographs could even raise questions of credibility. The reader seldom asks the origin of a news story, even if it arrives from a distant location to the local newspaper. Unusual photographs, however, particularly if taken inside factory gates, could arouse the very suspicion of bias which the use of the newspaper was to allay.

But perhaps a more pragmatic reason also influenced NELA's decision not to use photographs extensively. Its materials generally 
were prepared in New York in such a way that they later could be adapted to local conditions. A typical story would be rewritten by the local bureau, adding the names of pertinent local companies and cities, as well as the names of local citizens. Photographs were not sufficiently general to be adapted to the many localities where NELA's publicity appeared. The very concreteness of photographs, while it compelled belief, also limited their use. ${ }^{27}$

In the case of the Ripley "Romance of Power" lecture, however, personal bias could not be hidden, and the photograph reappeared as a strategic ally of corporate "truth." ${ }^{28}$ In the darkened hall, Ripley or his fifty surrogates remained invisible, while the audience displaced its attention to the slides. Thus the apparent exception to the general rule that NELA preferred not to use many photographs, proves its accuracy. The slides performed the objectifying function otherwise performed by the newspaper. They authenticated the speaker's argument in situations where the audience could see him, and know the origin of the message. In effect, the photographs played the same role as the trained animal in the circus, apparently acting as independent agents in tandem with the speaker's remarks. Of course the circus animal lives, and the photographs only echo moments of life, but the structural parallel remains the same. In each case, communication takes place through a sleight of hand. Just as the trainer has prepared the animal over many months to respond to hidden cues, so too corporate photographs are carefully designed so that they seem to depict the world, but they only mirror the corporation's view of it.

Once an audience accepts the substitution of an image for reality, the accompanying text stands in a new relation to it. The photograph becomes the signified, or the point of reference, while the text becomes its signifier. And an audience with access to both will naturally prefer to look at the "real" thing rather than read or hear about it. The text only seems to explain the photograph, when in fact the image legitimizes the text's description of it. The words spoken by a traveling lecturer to accompany an illustrated talk become credible to an audience in much the same way that an article becomes credible when inserted in a newspaper.

The photograph acts as a decentering device, pulling attention away from an argument that the corporation wishes to make, and permitting it to pass as commentary. Only in public relations can such a powerful tool be discarded, since a newspaper provides another kind of blind for the corporation to hide behind. Photography might seem to be an ideal or even indispensable tool in public relations, but in 
practise it has less need for photographs than advertising. This is because both public relations and corporate photography are ideological forms that masquerade as objective truth. Combining them in one communication is not only redundant, it may inadvertently reveal to an audience the difference between the overt and the covert senders of the message.

The advantages of indirect communication were not limited to a single transmission of the message through a third party. Often the original story would attract the attention of public speakers, publications, or authors, who then drew upon it for information. In this way, a message originally planted in but one publication might circulate through many others, losing all direct connection with the agency that first sent it out. In such cases, the corporations were entirely hidden as the original senders of the message. Between them and a reader lay an organization such as NELA, a bogus news agency created by NELA in a particular region, a newspaper, and the publication that reprinted or restated the story.

Public relations as a form is far from being a slight variation of advertising, and the differences make public relations much more influential. Studies of American popular culture that emphasize advertising alone miss an important agent of social change. As early as 1920 the budgets used in public relations approached those devoted to advertising, while the potential impact of these expenditures was far greater. For quantitative considerations do not get to the nature of public relations. It messages were enhanced through insertion in new contexts; republication amplified their range and further obscured their origins. And corporations used these new means of transmission for political purposes. Public relations sold ideas, not products, in this case preserving a private system of electrical power. In 1978 the generating capacity of private electrical power plants in the United States was more than $500 \%$ that of public power, making more than eight billion dollars in profits. ${ }^{29}$

Private ownership now seems "natural," and the american public has long ceased to debate the question of who should own and control the electrical system.

\section{NOTES}

1. Alan Raucher, Public Relations and Business: 1900-1929 (Baltimore: Johns Hopkins University Press, 1968); Daniel Boorstin, The Americans (New York: Random House, 1974), p. 137; Stanley Aronotwitz, False Promises (New York: 
McGraw Hill, 1973), p. 95-111: Frank Luther Mott, American Journalism (Cambridge, Mass: Harvard University Press, Third Edition, 1962); Edwin and Michael Emery, The Press and America: A $n$ Interpretative History of the Mass Media (Englewood Cliffs, New Jersey; Prentice Hall, 1978).

2. Books on Municipal Ownership, Brooklyn Public Library (New York: Brooklyn, 1906). The United States Library of Congress also published a bibliography in the same year, "Select List of Books on Municipal Affairs with Special Reference to Municipal Ownership," Washington, D.C., Library of Congress.

3. See, for example, the following very short list: John Bums, "Municipal Ownership a Blessing," Independent, 60, Feb. 22, 1906, 449-462; Richard T. Ely, "Municipal Ownership of Natural Monopolies", North American Review, 172, March, 1901, 445-55. "Fear of Municipal Socialism," Outlook, 76, April 23, 1904, 965-68. Louis D. Brandeis, "How Boston Solved the Gas Problem," Review of Reviews, 36, Nov. 1907, 594-598.

4. Utility Corporations Document 92, United States Senate, 70th Congress First Session, 1928. Published in 71 parts over seven years. The enormous volume of materials are indexed in volume 71 , and the index alone is more than 530 pages.

5. The summary of the pro-public ownership position is drawn from a large number of sources, inclu ng those cited in footnote three, and also the following: Charles Whiting Baker, Monopolies and the People. (New York: Macmillan, 1899); Frederick C. Howe, City the Hope of Democracy (New York: Scribner's \& Sons, 1905); \& particularly Annals of the American Academy Vol. 27, which contains three useful articles, one on Glasgow, another on street railways in Germany, and a third on municipal ownership in Chicago.

6. Richard T. Ely, "Advantages of Public Ownership, and Management of Natural Monopolies," Cosmopolitan, 30, March 1901, 557-560.

7. The following paragraph based on these articles: Winthrop M. Daniels, "Municipal Ownership" in Publications of the American Economic Association, 1906, 9: 133-143; Roland Phillips, "Problem of Municipal Ownership," Harper's Weekly, 51, September 14, 1907, 1344. "Municipal Socialism," Quarterly Review 205, October, 1906, 420-438.

8. See, for example, T.L. Hicks, "Philadelphia Gas Works under Private Operation," World Today, October, 1907, 1037; \& Ernest E. Williams, "How London Loses by Municipal Ownership," North American Review, 183, October, 1906, 729-736.

9. See David E. Nye, Henry Ford: Ignorant Idealist (Port Washington: Kennikat Press, 1979), 24-26; Ernest Gruening, The Public Pays: A Study of Power Propaganda (New York: Vanguard Press, 1931), 144, 171-73. Utility Corporations, op.cit., index lists more than thirty publications issued by NELA and others during the 1920's, see volume 71, 195-198.

10. For a summary of the activities of NELA during the period from 1915 until it came under investigation, see Utility Corporations, op.cit. Document 92, Part 72A, 23-31.

11. Ibid., 28-29; and see Greuhing, op.cit. 131-210.

12. Greuning, op.cit., particularly 174-182. Also see Jack Levin, Power Ethics New York: Alfred A. Knopf, 1931), 112-122, which contains choice quotations from the Senate sponsored hearings.

13. Ibid. (Levin), 123-133.

14. Ibid., 122; Greuning, op.cit., 178-183.

15. Alan Raucher, op.cit. 75-93. 
16. Paul Bouissac, Circus and Culture (Bloomington; Indiana University Press, 1976), see "The Performing Horse," 52-63.

17. See "'Clever Hans' in a semiotic Frame," by Thomas A. Sebeok in Diogenes, 28, 1978. Also, Professor Sebeok discussed the case of Clever Hans at length in March, 1981, with the author.

18. Roman Jakobson, "Linguistics and Poetics," p. 353 in Thomas A. Sebeok's Style in Language (Cambridge, Mass: M.I.T. University Press, 1960), states the original version of this model. That presented here comes from Umberto Eco's A Theory of Semiotics (Bloomington: University of Indiana Press, 1979), p. 141.

19. The Stewart case was discussed in a paper delivered to the National Convention of the American Political Science Association in December, 1928, and later published as The Challenge of the Power Investigation to American Educators by Judson King (Washington, D.C.: National Popular Government League, April 1929). Copy in Harvard's Widener Library.

20. Ibid., 24-25.

21. On NELA educational propaganda, see Levin, op.cit., 70-80 $2 / 3$ lower schools $3 / 4$, 81-86 2/3colleges $3 / 4,94-95^{2 / 3}$ power conferences $3 / 4,134-1402 / 3$ public speaking $3 / 4$. Also Greuning, op.cit., 82-107 2/3rewriting textbooks $3 / 4,211-230$ 2/3radio, screen, and music $3 / 4$, and passim. For further information consult Utility Corporations Index, op.cit.

22. On Swope, see Utility Corporations, op.cit., Part 71-B, 398. On Young, Ibid., $438,545$.

23. Ibid., Document 92, Part Three, 14-16.

24. Ibid., Document 92, Part Four, 224-225; 278 ("The 'Romance of Power,' is a compilation of slides showing the drudgery of a lot of the people in the world in Europe and Asia.")

25. Gruening, op.cit., 138-139.

26. Utility Corporations, op.cit., Part Four, 279-280; Part Five, 17-19.

27. This generalization most emphatically does not apply to overt public relations, however. See the nine photographic advertisementsfor private power reprinted in the 1964 edition of Gruening, op.cit. between pages xxvii and xxix. One, for example, depicts a baby being spoonfed, his face smeared with baby food, while he smacks his lips. The text begins, "Year-old Alexander Maier of Dayton, Ohio, is one of the newest of the 94 million owners of America's electric light and power companies ..." The ad concludes that anyone with a savings account "participates in the profits of the industry." Another ad shows an elderly couple being turned back into East Berlin by armed guards. The text emphasizes that freedom can slip away when the federal government gets too involved in business.

28. Utility Corporations, op.cit., Part Four, 279, contains the only description of the contents of The Romance of Power lecture or book. The work itself has entirely disappeared. No copy exits in the Library of Congress, the New York Public Library, Harvard University's Widener Library, or even the General Electric library in Shenectady. The University of Idaho is listed in the Union Catalogue as having a copy, but it could not be located when requested. The sets of slides have also disappeared, but a number of images in the General Electric Archives from c. 1926-27 appear quite likely as possible candidates for the lecture.

29. Statistical Abstract of the United States, 100th edition, (Washington, D.C.: United States Department of Commerce, 1979.) pages 611-612. 